\title{
Iron-bearing Oolites and the Present Conditions of Iron Sedimentation in Lake Chad (Africa)
}

\author{
J. Lemoalle and B. Dupont
}

\begin{abstract}
The oolites are found at a depth of 1 to 3 meters of water, in a zone of about $2700 \mathrm{sq}$. $\mathrm{km}$, off the Chari delta. The grain size is around $0.250 \mathrm{~mm}$. Montmorillonite nuclei are surrounded by goethite and silica, the iron content attains a maximum value of $49 \% \mathrm{Fe}_{2} \mathrm{O}_{3}$. Pollen analyses show a lacustrine formation. The present chemical conditions lead to a scheme of iron behaviour in which colloidal or adsorbed iron from the solid load of the incoming rivers (940oo tons reactive iron in 1970-71) is separated from kaolinite, which becomes unstable in the lake, and forms a coprecipitate with silica.
\end{abstract}

\section{Résumé}

Les oolithes se trouvent sous 1 â 3 mètres d'eau, sur une surface de $2700 \mathrm{~km}^{2}$ environ, au large du delta du Chari. Leur taille est de $0,250 \mathrm{~mm}$ environ. Les noyaux de montmorillonite sont entourés de goethite et de silice, la teneur en fer atteignant $49 \%$ en $\mathrm{Fe}_{2} \mathrm{O}_{3}$. Les analyses polliniques indiquent une formation lacustre. Les conditions chimiques actuelles dans le lac permettent de présenter un schéma du comportement du fer dans lequel le fer colloidal ou adsorbé apporté par le fleuve ( 94000 tonnes de fer réactif en 1970-71) se sépare de la kaolinite, qui sort alors de son domaine de stabilité, et forme un coprécipitê avec la silice.

The Chad basin provides an ideal example of a closed continental basin which allows us to follow, in time and space, the different steps of erosions, transportation and sedimentation of the dissolved and particulate elements. Some observations and results dealing with the transportation and sedimentation of iron in the lower part of the basin are presented here.

\section{Observations}

Lake Chad lies between parallels $12^{\circ} 20$ and $14^{\circ} 20$ North, and is divided between four states: Niger, Nigeria, Cameroun and Chad. Its largest dimension from the Chari delta is $230 \mathrm{~km}$; its area $24000 \mathrm{sq} . \mathrm{km}$, and its average depth $3.5 \mathrm{~m}$. Islands and "bankislands", shallows on which reeds and papyrus have grown, cover its north-eastern part; they are the tops of some dunes of an ancient and partly immersed erg (fig. 1).

The lake is a closed basin fed by the Chari River. Its water amounts to $83 \%$ on the average of the total influx; rains and other tributaries contribute 13 and $5 \%$ respectively. The Chari and its main affluent, the Logone, originate in a humid tropical climate on the northern side of the Central ridge which, in the Central African Republic, divides the waters between the Chad and the Congo basin. From west to east one can distinguish several zones in the upper part of the basin according to the nature

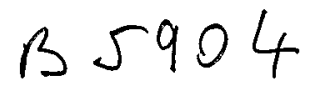




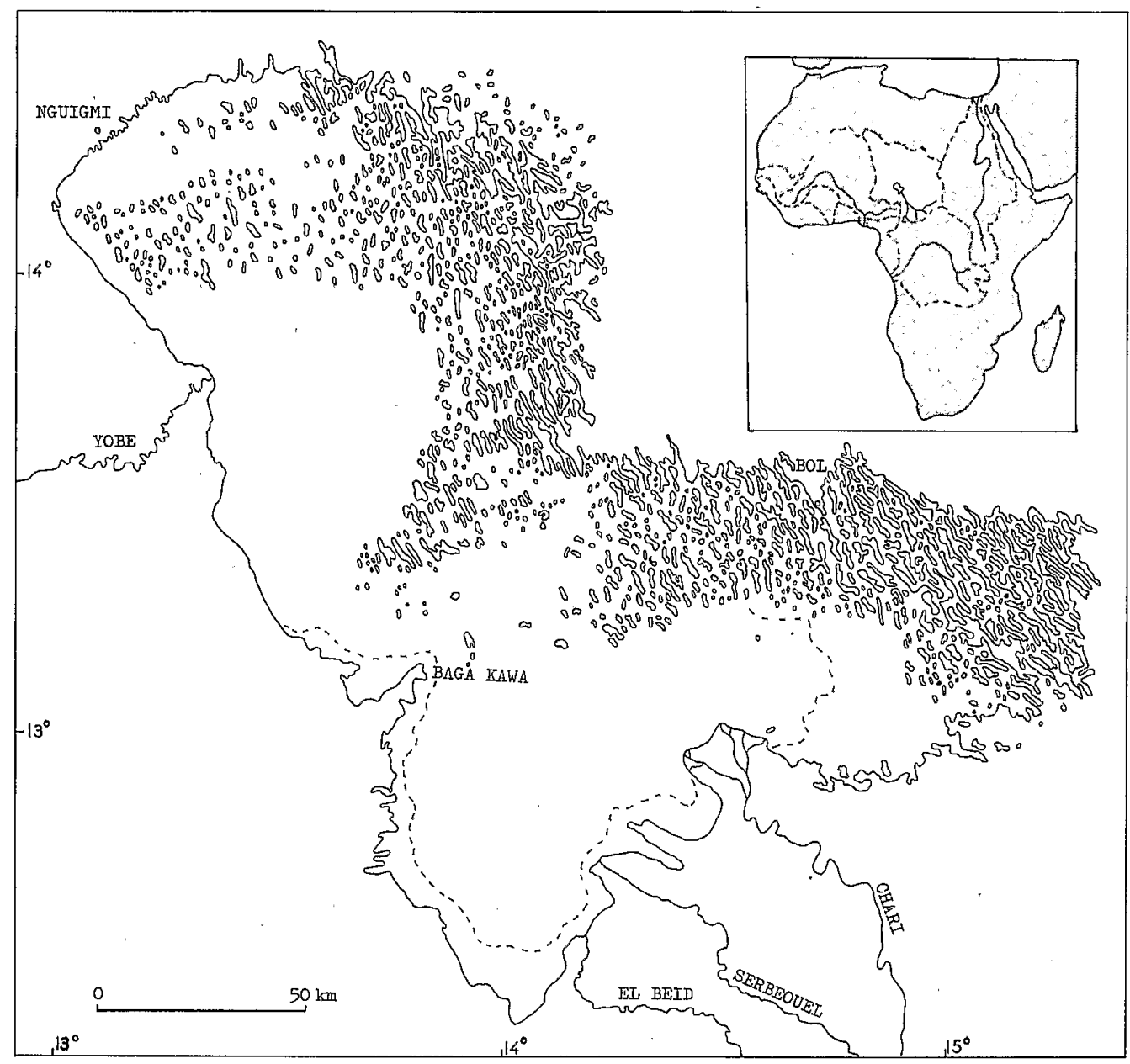

Fig. 1. Lake Chad and the geographical location of the Chad Basin

of the substratum; the river system is dense on granites and migmatites, moderately dense on gneiss, mica-schist and quartzite, and rather open on sandstones.

Waters reaching the lake are fresh $\left(25^{\circ} \mathrm{C}\right.$ conductivity: $60 \mathrm{micromhos} / \mathrm{cm}$ on the average); the most important solids brought by the river are quartz and clay, mainly kaolinite, with montmorillonite being absent from the analyzed samples (GAC, private communication). The fine fraction of the lake sediments, on the other hand, is composed of montmorillonite; kaolinite and illite appear only as traces.

The lake sediments (DUPONT, 1970) can be divided into four main types, often related to the emerged landscape (fig. 2):

- Mud, rich in organic matter (13\% dry weight) is present in the whole band-islands zone.

- Clay appears under several aspects according to its degree of compaction and covers the bottom of the open-waters near the bank islands zone. Clay and mud cover the bottom of the whole archipelago. 


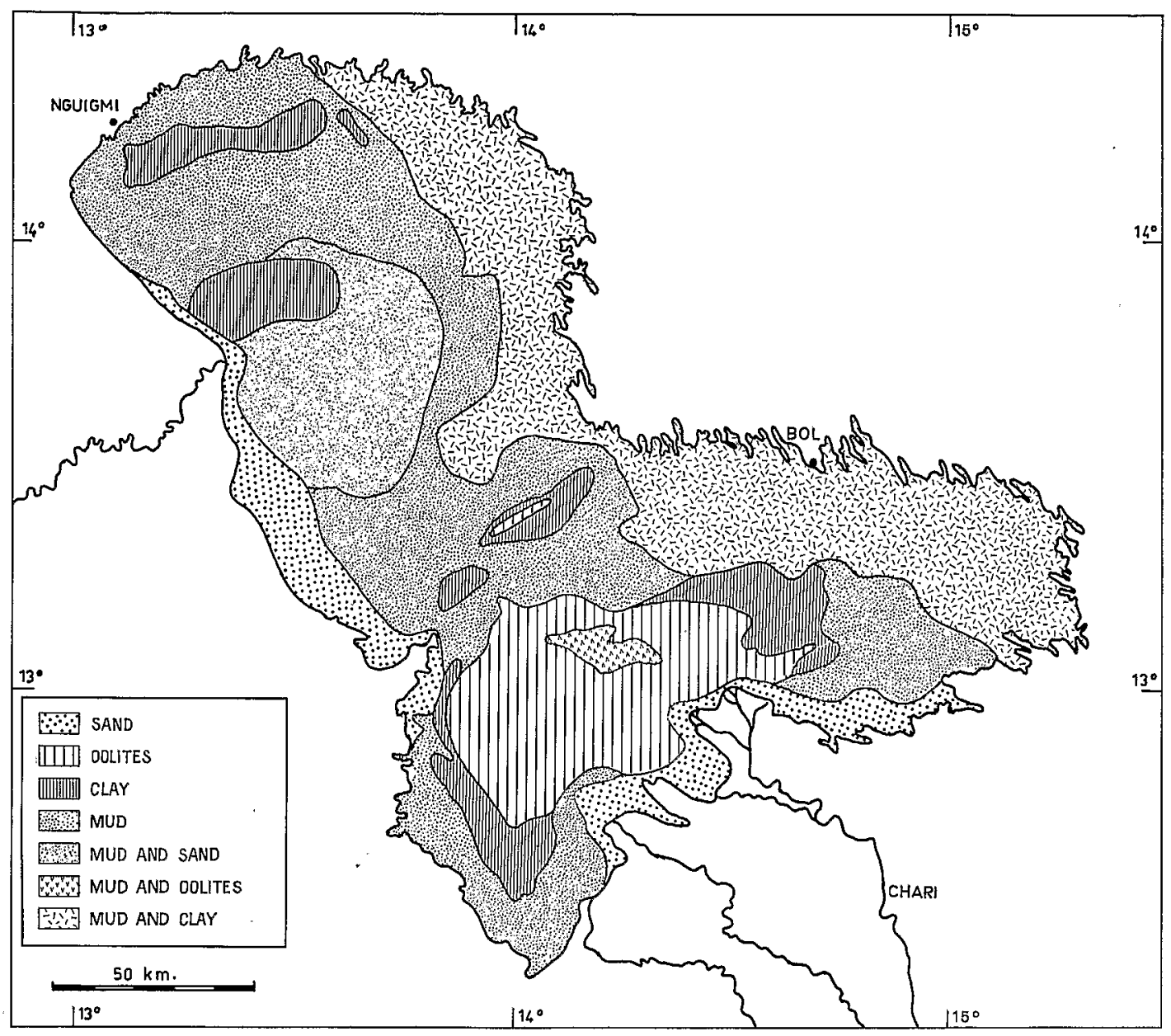

Fig. 2. The sediments of Lake Chad

- Sands are fine and well sorted and originate from two different stocks. The first one derives from the erg lying north-east of the lake and is almost entirely quartzous. The second one is micaceous and was brought by the rivers. It constitutes the sediments along the shore near the deltas of the Chari and Yobe rivers. The iron content of the sand is about $0.5 \%\left(\mathrm{Fe}_{2} \mathrm{O}_{3}\right)$, but locally, in the zone of oolites, the grains are covered with a film of oxide and the amount of iron can reach $27 \%$.

- The iron-bearing oolites with a size similar to that of the sands are found on the bottom of a large zone of open-waters off the Chari delta.

\section{The oolites}

First described by GUICHARD (1957) as "pseudo-sable", the oolites of Lake Chad are small, round shaped, polished or cracked grains of brown color when dry (fig. $3 \mathrm{a}, 3 \mathrm{~b})$. When wet, they look like coffee grounds. They form a layer of variable thick- 
ness, up to $40 \mathrm{~cm}$, including one or two local clay intercalations. They always lay on clay and are sometimes covered with mud. The oolites are found at a depth of 1 to 3 meters of water in a zone of about $2700 \mathrm{sq}$. $\mathrm{km}$, westwards off the Chari delta (fig. 2). No oolites have been found towards the east, off the fossil estuaries of the Chari, the latest of which has been flowing till about 150 A. C. (PIAS, 1970). This geographical location seems to assign them a recent origin related to the present course of the Chari River. This origin may be allochthonous, brought as detrital oolites by the Chari, or autochthonous by precipitation of the iron brought by the river.

The nature and origin of these oolites has been investigated by some analyses and obs ervations.

The grain size distribution has a single mode at $0.250 \mathrm{~mm}$, medians ranging from 0.205 to $0.283 \mathrm{~mm}$. TRASK's sorting index, close to 1.2 , indicates a well sorted material.
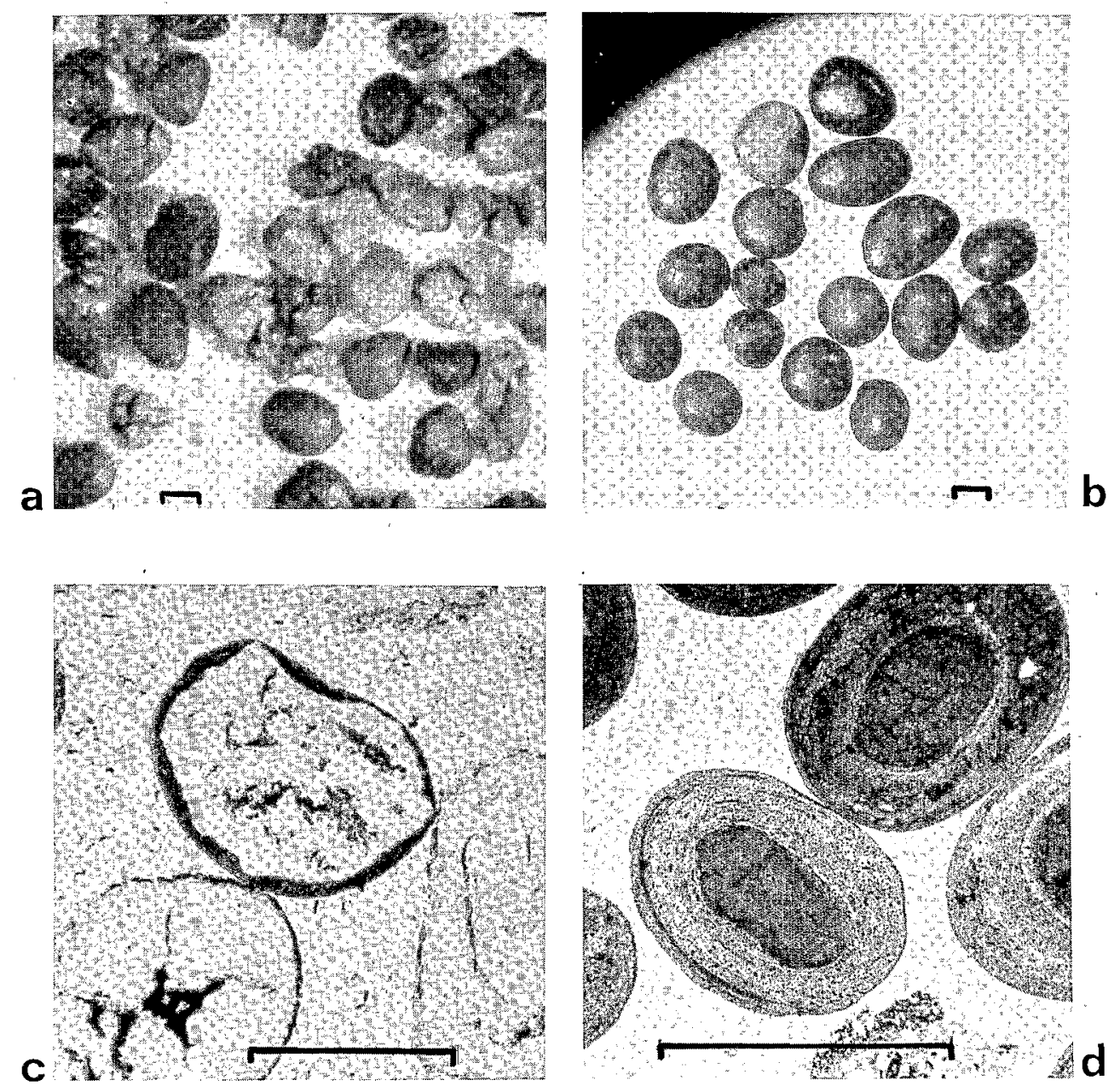

Fig. 3. Oolites. Top, $a$ and $b$; the line is $0.2 \mathrm{~mm}$ long. Bottom, $\mathrm{c}$ and $\mathrm{d}$, thin sections; the line is $0.5 \mathrm{~mm}$ long 
Thin layer observations show several grain types according to a more or less matured state of the oolites. In the first state, light yellow-brown nuclei of clay, and sometimes quartz, are covered by a thin, i. e. a few microns thick dark cortex. Some nuclei had small internal cracks into which oxides entered; others display bare cracks (fig. $3 \mathrm{c}$ ). The most matured grains have a clay nucleus covered by a thick reddish cortex (10 to 15 microns) exhibiting a clear oolitic structure (fig. 3d).

$\mathrm{X}$-ray diffraction analysis has shown that the main crystallized minerals are montmorillonite and goethite. Kaolinite, quartz and calcite peaks also appear. The presence of calcite can be accounted for by the large quantity of molluscs (Corbicula africana) living on the oolite deposits.

By chemical analysis other features of the oolites were brought out: Concentrated hydrochloric acid released the iron into solution, but did not alter the shape of the oolites. After rinsing, the cortex (which may have split) appeared as a white, porous and siliceous framework revealing the association between iron and silica (table I).

A comparison between the load of solids of the river, lacustrine clays and oolites showed that the titanium to alumina ratio remained fairly constant while the ratios iron to alumina and silica to alumina increased considerably, the former passing from 0.5 to 30 , and the latter from 2.5 to 36 , in the river and the oolites respectively. Manganese is also concentrated in the oolites, but more irregularly than iron.

Consequently, a very large increase in silica, iron and manganese in regard to alumina is seen in the oolites and, to a lesser extent, also in some samples of granular "clay" taken from the border along the zone of oolites.

A pollen analysis was made ${ }^{1}$ ) on two samples of washed oolites. These were treated according to the standard method followed by acetolysis (FAEGRI and IVERSEN, 1964).

When referring to the present vegetation (MALEY, 1970) and to other pollen analyses of recent and subrecent sediments of the Lake (MALEY, unpublished), it appears that the pollen spectra of the oolites are very similar to those of the sediments in the same region of the Lake. They are characterized by the prevalence of the local vegetation (Graminaceae) surrounding the water and of Lake Chad vegetation (Cyperaceae, Typha, Aeschinomene elaphroxylon) and also by the very low proportion of the allochthonous pollen grains carried from the sudanian zone by the river (table II).

From these observations some conclusions can be drawn

- in favour of the autochthony of the oolites: pollen spectra pointing to a lacustrine formation, absence of such oolites in the Chari alluvial deposits;

- in favour of the recent nature of the deposit: the oolites are located only off the present Chari delta and almost no other sediment is found on top of the oolite layer.

\section{Present conditions of iron sedimentation}

These observations led us to the analysis of some elements of the present transportation and sedimentation of iron in the lower Chari and in Lake Chad, i. e. the nature and quantity of the incoming iron, and chemical evolution of the waters and the particles in the Lake.

1) Analysed by J. MALEY, O.R.S. T.O. M. , Fort Lamy 
Table I - Chemical analyses of some sediments of Lake Chad

\begin{tabular}{|c|c|c|c|c|c|c|c|c|c|c|c|c|c|}
\hline No. & Nature & $\begin{array}{c}\text { Ignition } \\
\text { loss } \\
\%\end{array}$ & $\begin{array}{c}\text { Quartz and } \\
\text { non solubles } \\
\%\end{array}$ & $\begin{array}{c}\text { Total } \\
\text { phosphorus } \\
\%_{0}\end{array}$ & $\begin{array}{c}\mathrm{SiO}_{2} \\
\%\end{array}$ & $\begin{array}{c}\mathrm{Al}_{2}{ }^{0} 3 \\
\%\end{array}$ & $\begin{array}{c}\mathrm{Fe}_{2} \mathrm{O}_{3} \\
\%\end{array}$ & $\begin{array}{c}\mathrm{TiO}_{2} \\
\%\end{array}$ & $\begin{array}{c}\mathrm{MnO}_{2} \\
\%\end{array}$ & $\mathrm{Ca} 0$ & $\mathrm{Mg} 0$ & $\begin{array}{c}\mathrm{K}_{2} \mathrm{O} \\
\%\end{array}$ & $\mathrm{Na}_{2} \mathrm{O}$ \\
\hline $\begin{array}{l}010 \\
013 \\
011 \\
012\end{array}$ & $\begin{array}{l}\text { Solid load, Logone } \\
\text { Solid load, Logone } \\
\text { Solid load, Chari } \\
\text { Solid load, Chari }\end{array}$ & $\begin{array}{l}11.2 \\
11.2 \\
13.4 \\
12.9\end{array}$ & $\begin{array}{r}22.3 \\
26.1 \\
8.9 \\
18.1\end{array}$ & $\begin{array}{l}2.52 \\
2.26 \\
1.76 \\
1.80\end{array}$ & $\begin{array}{l}31.2 \\
30.1 \\
40.0 \\
34.3\end{array}$ & $\begin{array}{l}21.4 \\
20.1 \\
26.3 \\
23.5\end{array}$ & $\begin{array}{l}9.25 \\
8.50 \\
7.20 \\
7.40\end{array}$ & $\begin{array}{l}1.56 \\
1.38 \\
1.08 \\
1.08\end{array}$ & $\begin{array}{l}0.045 \\
0.045 \\
0.035 \\
0.040\end{array}$ & $\begin{array}{l}0.30 \\
0.28 \\
0.25 \\
0.34\end{array}$ & $\begin{array}{l}0.67 \\
0.65 \\
0.46 \\
0.46\end{array}$ & $\begin{array}{l}0.60 \\
0.61 \\
0.60 \\
0.64\end{array}$ & $\begin{array}{l}0.26 \\
0.22 \\
0.22 \\
0.32\end{array}$ \\
\hline $\begin{array}{l}969 \\
1432 \mathrm{~A} \\
1432 \mathrm{~F} \\
1432 \mathrm{~K} \\
1467 \\
1469 \\
1454\end{array}$ & $\begin{array}{l}\text { Clay, granular } \\
\text { Clay, blue } \\
\text { Clay, blue } \\
\text { Clay, blue } \\
\text { Clay, granular } \\
\text { Clay, granular } \\
\text { Clay, blue }\end{array}$ & $\begin{array}{r}12.4 \\
11.9 \\
16.3 \\
14.3 \\
15.7 \\
18.5 \\
8.1\end{array}$ & $\begin{array}{l}11.0 \\
12.5 \\
16.3 \\
17.3 \\
17.2 \\
6.15 \\
54.9\end{array}$ & $\begin{array}{l}1.80 \\
0.89 \\
8.95 \\
0.87 \\
1.41 \\
0.78 \\
1.25\end{array}$ & $\begin{array}{l}40.0 \\
43.3 \\
40.3 \\
40.1 \\
34.3 \\
36.8 \\
18.2\end{array}$ & $\begin{array}{r}14.4 \\
19.5 \\
21.3 \\
17.6 \\
11.0 \\
5.3 \\
9.7\end{array}$ & $\begin{array}{r}17.00 \\
7.50 \\
8.00 \\
6.75 \\
17.50 \\
28.50 \\
6.50\end{array}$ & $\begin{array}{l}0.55 \\
1.00 \\
0.93 \\
0.64 \\
0.85 \\
0.29 \\
1.04\end{array}$ & $\begin{array}{l}0.050 \\
0.085 \\
0.045 \\
0.035 \\
0.075 \\
0.125 \\
0.075\end{array}$ & $\begin{array}{l}1.16 \\
0.65 \\
0.65 \\
0.60 \\
1.17 \\
1.50 \\
0.54\end{array}$ & $\begin{array}{l}1.04 \\
0.95 \\
0.94 \\
0.84 \\
0.98 \\
0.98 \\
0.49\end{array}$ & $\begin{array}{l}0.56 \\
0.80 \\
0.75 \\
0.68 \\
0.51 \\
0.39 \\
0.42\end{array}$ & $\begin{array}{l}0.41 \\
0.23 \\
0.23 \\
0.25 \\
0.18 \\
0.19 \\
0.18\end{array}$ \\
\hline $\begin{array}{l}1094 \\
1455 \\
1457 \\
1459 \\
1461 \\
1463 \\
1465 \\
1479 \\
1483\end{array}$ & $\begin{array}{l}\text { Oolites (large) } \\
\text { Oolites } \\
\text { Oolites } \\
\text { Oolites } \\
\text { Oolites } \\
\text { Oolites } \\
\text { Oolites } \\
\text { Oolites } \\
\text { Oolites }\end{array}$ & $\begin{array}{l}8.70 \\
7.30 \\
7.50 \\
8.55 \\
7.40 \\
7.35 \\
8.55 \\
7.50 \\
7.70\end{array}$ & $\begin{array}{r}0.40 \\
13.90 \\
2.35 \\
2.20 \\
2.25 \\
4.05 \\
6.90 \\
1.45 \\
4.80\end{array}$ & $\begin{array}{l}4.36 \\
2.18 \\
1.68 \\
0.95 \\
0.63 \\
0.86 \\
0.76 \\
0.78 \\
1.35\end{array}$ & $\begin{array}{l}35.0 \\
33.0 \\
43.8 \\
43.1 \\
45.1 \\
45.2 \\
41.8 \\
43.5 \\
38.8\end{array}$ & $\begin{array}{l}1.75 \\
2.15 \\
2.70 \\
4.00 \\
3.15 \\
3.00 \\
3.70 \\
2.00 \\
1.85\end{array}$ & $\begin{array}{l}49.5 \\
39.1 \\
39.1 \\
37.9 \\
37.9 \\
36.0 \\
34.5 \\
40.5 \\
41.0\end{array}$ & $\begin{array}{l}0.09 \\
0.10 \\
0.13 \\
0.20 \\
0.15 \\
0.15 \\
0.23 \\
0.08 \\
0.08\end{array}$ & $\begin{array}{l}0.288 \\
0.520 \\
0.400 \\
0.225 \\
0.145 \\
0.155 \\
0.110 \\
0.225 \\
0.235\end{array}$ & $\begin{array}{l}1.18 \\
1.27 \\
1.46 \\
1.47 \\
1.47 \\
1.44 \\
1.32 \\
1.69 \\
1.54\end{array}$ & $\begin{array}{l}1.13 \\
1.05 \\
1.25 \\
1.25 \\
1.27 \\
1.31 \\
1.16 \\
1.39 \\
1.31\end{array}$ & $\begin{array}{l}0.18 \\
0.14 \\
0.19 \\
0.22 \\
0.16 \\
0.16 \\
0.40 \\
0.17 \\
0.20\end{array}$ & $\begin{array}{l}0.16 \\
0.18 \\
0.21 \\
0.20 \\
0.17 \\
0.13 \\
0.19 \\
0.13 \\
0.20\end{array}$ \\
\hline
\end{tabular}


Table II - Pollen analysis of some oolites

Sample $931 \quad$ Sample 1094

Lacustrine vegetation

Cyperaceae

Typha

Aeschynomene elaphroxylon (Papil.)

59

23

2

31

2

Total

84

36

Per cent

$57 \%$

$47.3 \%$

\section{Local sahel vegetation}

Graminaceae
Phyllanthus rotundifolius (Euph.)
Compositae
Combretum sp.
Mitracarpus scaber (Rub.)
cf. Celosia trigyna (Amaran.)

Total

Per cent
40

$-$

-

2

1

1

44

$29.3 \%$
31

1

1

$-$

$-$

33

$43.4 \%$

Allochthonous sudanian vegetation

Uapaca sp.

Alchornea cordifolia (Euph.)

Oleacea type

cf. Adina sp. (Rub.)

Ulmaceae.

Total

Per cent

$\underline{\text { Undetermined }}$

16

6

$\underline{\text { Total observed }}$

149

76

It has been established by filtration experiments (LEMOALLE, 1969) that the concentration of dissolved iron is very low, i. e. lower than $50 \mu \mathrm{g} / 1$, in the Chari and in the lake waters as well. The pH and oxidation conditions and the very low quantities of dissolved organic matter do not allow the presence of large concentrations of soluble or complexed iron. Soluble iron is therefore negligible compared to the iron present as solid sludge particles, and is neglected in the value of total iron. The charge of the sludge particles containing iron has been determined by electrophoresis. It is either negative or zero. 
Dissolved iron being neglected, we have looked for that part of particulate iron which was able to react rather easily. This reactive iron (extracted in boiling $4 \% \mathrm{HCl}$ during 10 minutes, STRICKLAND and PARSONS, 1965) closely corresponds here to free iron as determined by DEB (1950), that is, particulate or adsorbed oxides and hydroxides (FRIPIAT and GASTUCHE, 1952) and represents about half of the total iron determined after alkaline fusion or triacid attack.

Weekly measurements on the Chari and Logone Rivers before their confluence allowed to measure that reactive iron amounts to $3.6 \%$ of the solid load.

Maximum reactive iron concentration occurs at the beginning of the flood (fig. 4 ) and reaches very high valües (30 $\mathrm{mg} / \mathrm{l}$ ) in the Logone. During $1970-71$, when an average amount of water was measured, 94000 metric tons of reactive iron reached the Lake.

Subjected to evaporation, the Lake water increases in salinity progressively from the delta and reaches values which are five and ten times higher in the east and in the
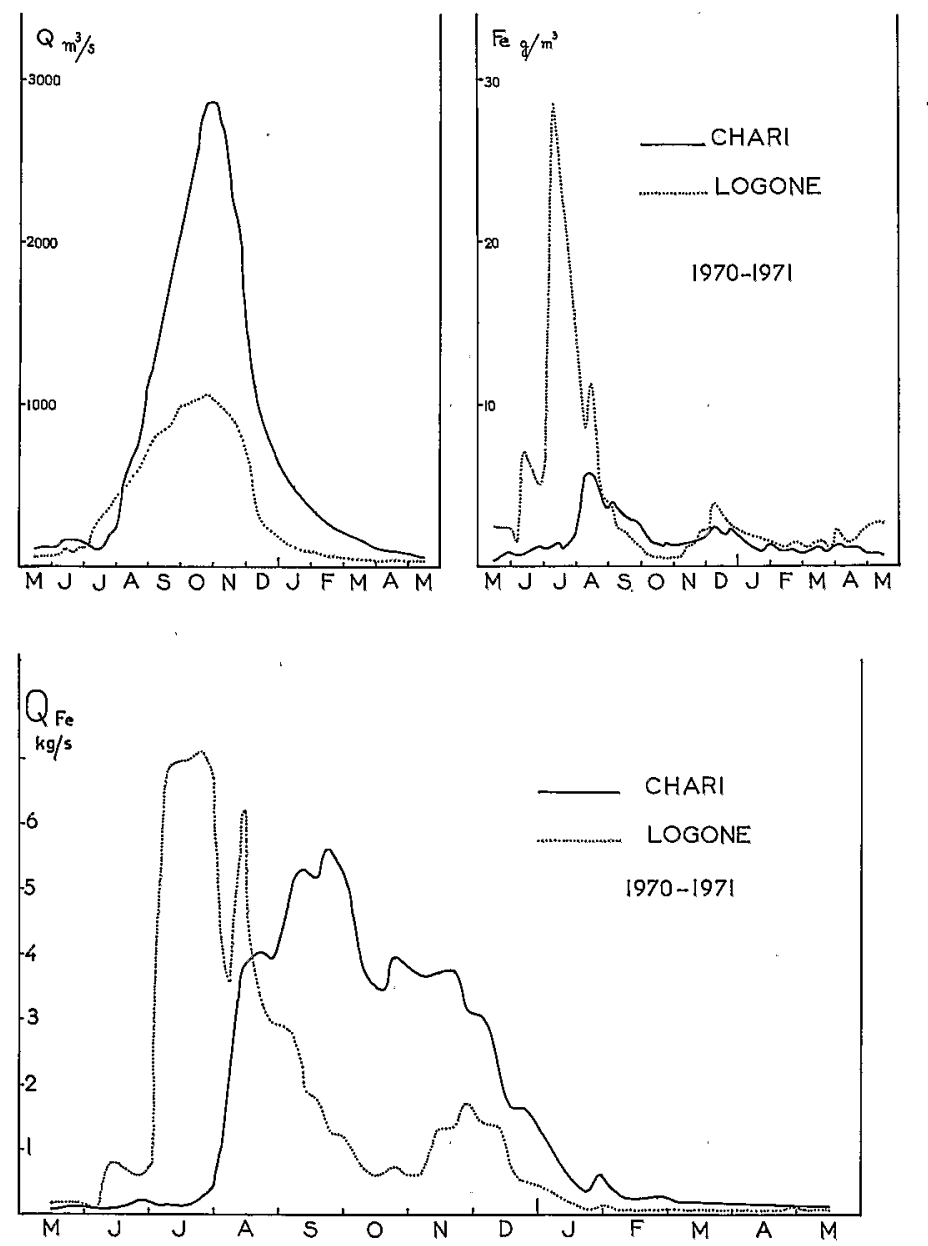

Fig. 4. Hydrograms $\left(\mathrm{m}^{3} / \mathrm{s}\right)$, reactive iron concentrations $\left(\mathrm{g} / \mathrm{m}^{3}\right)$ and iron flow $(\mathrm{kg} / \mathrm{s})$ in the Chari and Logone Rivers at Fort Lamy. Their sum is the inflowing quantity of iron received by the Lake 
north, respectively, with some modifications in the ionic composition (CARMOUZE, 1970).

The mean composition of two stations are given here, i. e. the Chari Delta and Bol station located in the archipelago of the eastern zone where the ionic concentration is about twice as high.

\begin{tabular}{l|cccccccc} 
& $\begin{array}{c}\mathrm{C} \\
\begin{array}{c}\mu \mathrm{mhos} / \\
\mathrm{cm}\end{array}\end{array}$ & $\begin{array}{c}\mathrm{pH} \\
\mathrm{HCO}_{3}^{-} \\
\mathrm{me} / 1\end{array}$ & $\begin{array}{c}\mathrm{Na}^{+} \\
\mathrm{me} / 1\end{array}$ & $\begin{array}{c}\mathrm{K}^{+} \\
\mathrm{me} / 1\end{array}$ & $\begin{array}{c}\mathrm{Ca}^{++} \\
\mathrm{me} / 1\end{array}$ & $\begin{array}{c}\mathrm{Mg}^{++} \\
\mathrm{me} / 1\end{array}$ & $\begin{array}{c}\mathrm{SiO}_{2} \\
\mathrm{mg} / 1\end{array}$ \\
\hline Delta & 60 & 6.9 & 0.70 & 0.16 & 0.06 & 0.27 & 0.21 & 24 \\
Bol & 120 & 7.8 & 1.39 & 0.37 & 0.10 & 0.53 & 0.40 & 34
\end{tabular}

The importance of biological factors, mainly photosynthesis in the $\mathrm{pH}$ regulation, must not be overlooked, the $\mathrm{pH}$ decreasing quickly when photosynthesis ceases (LEMOALLE, 1969).

Reactive iron is more or less bound to clay particles. It is therefore important to know how the clay particles behave in the Lake. Equilibria between kaolinite and montmorillonite, which are the two main clay mineral species, are presented in two diagrams (fig. 5) corresponding with the following reactions:

$$
\begin{aligned}
& \text { kaolinite }+\mathrm{SiO}_{2}+\mathrm{Na}^{+} \leftrightharpoons \text { montmorillonite } \mathrm{Na}+\mathrm{H}^{+} \\
& \text {kaolinite }+\mathrm{SiO}_{2}+\mathrm{Ca}^{2+} \leftrightharpoons \text { montmorillonite } \mathrm{Ca}+2 \mathrm{H}^{+}
\end{aligned}
$$

The equilibrium constants are, at a temperature of $25^{\circ} \mathrm{C}$ (ROBIE and WALDBAUM, 1968; TARDY, 1969):

$$
\begin{aligned}
& \mathrm{pK}=4 \log \left[\mathrm{H}_{4} \mathrm{SiO}_{4}\right]-\log \frac{\left[\mathrm{Na}^{+}\right]}{\left[\mathrm{H}^{+}\right]}=-9.31 \\
& \mathrm{pK}=8 \log \left[\mathrm{H}_{4} \mathrm{SiO}_{4}\right]-\log \frac{\left[\mathrm{Ca}^{2+}\right]}{\left[\mathrm{H}^{+}\right]^{2}}=-15.70
\end{aligned}
$$
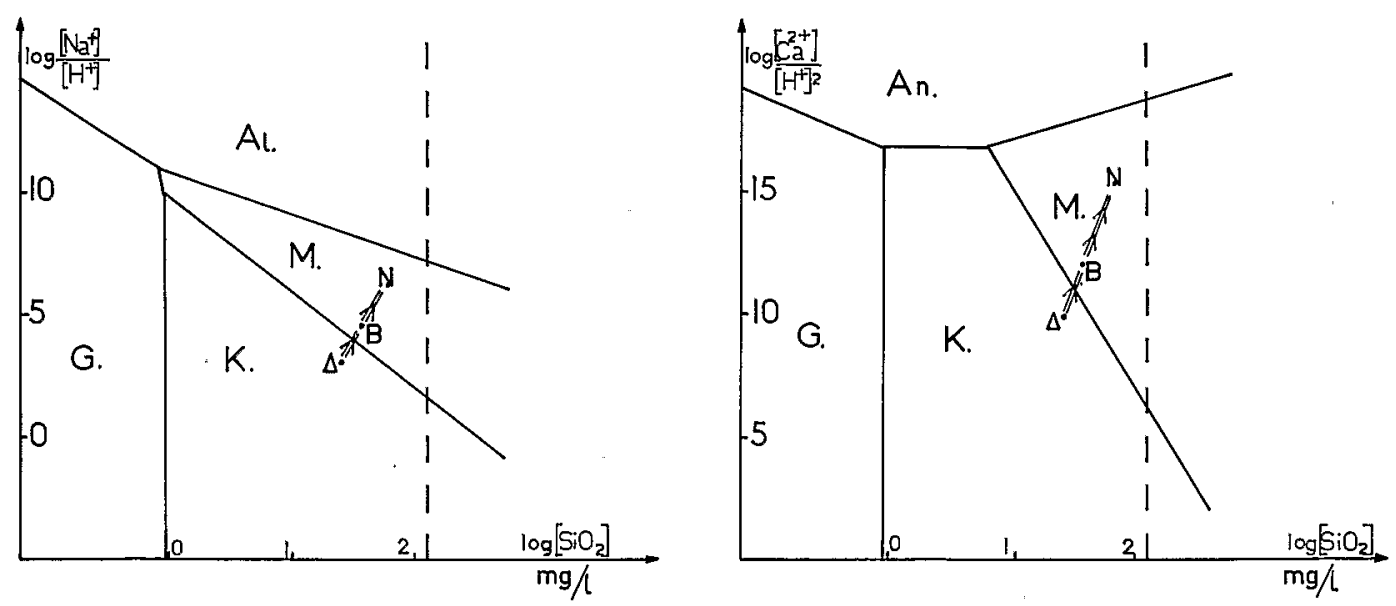

Fig. 5. Equilibrium diagrams between kaolinite and montmorillonite. $\mathrm{Al}=$ albite, $\mathrm{G}=$ gibbsite, $\mathrm{K}=$ kaolinite, $\mathrm{M}=$ montmorillonite, $\mathrm{An}=$ anorthite. Arrow indicates the water concentration starting from the estuary $(\Delta)$ to $\mathrm{Bol}(\mathrm{B})$ and to the most concentrated waters in the northern part of the Lake 
The Chari water reaching the Lake is represented by a dot inside the kaolinite stability field. From the delta the lake water concentrates by evaporation. The representative point in the diagram shifts and crosses the kaolinite-montmorillonite equilibrium line rather rapidly, even before the concentration is double.

Although not dealing with the kinetics of the reactions, these thermodynamic relations allow us to say that there may be transition in the Lake from kaolinite to montmorillonite. This transformation or instability may be of some importance in the separation of adsorbed oxides and hydroxides from clays.

\section{A scheme of iron behaviour}

The silica of rivers precipitates by adsorption and reaction with inorganic particles when pH and salinity increase through mixing with seawater in estuaries (BIEN et al., 1958; LISS and SPENCER, 1970). When flowing in Lake Chad, the pH and electrolyte concentration of the waters increase. Clay particles become unstable and iron, which settles rapidly in such conditions (COONLEY et al., 1971) is distributed between several types of sedimentary material.

The oxidized structure of the oolite cortex suggests a coprecipitation of silica and colloidal iron. The affinity of these two substances for each other is high (MORTIMER, 1941, 1942; FLEHMIG, 1970) and the molar composition of such a precipitate is a function of the medium $\mathrm{pH}$ and of the isoelectric points of its components (PARKS, 1967). When A and B are the isoelectric points of the iron oxides and of silica which react, the molar composition of the precipitate is a function of the $\mathrm{pH}$ and will be near the following expression:

$$
\% \mathrm{SiO}_{2}=\frac{\mathrm{A}-\mathrm{pH}}{\mathrm{A}-\mathrm{B}}
$$

Uncertainty on the $\mathrm{pH}$ values of the zero point of the charge of silica and iron does not allow an exact calculation of the precipitate composition. For a pH 7.0 to 7.5 the theoretical ratio of silica to iron is close to 1 . In the cortex of the oolites, this ratio is 0.86 on an average, with extreme values of 0.72 and 1.15 .

Iron and silica reacting together, there must be, elsewhere in the Lake, some sediments in which the alumina content is higher than in the solid load of the Chari; more analyses are being performed.

\section{Conclusion}

The first results of this work on the oolites of Lake Chad led to the conclusion that the deposit is autochthonous and recent. A study of the present conditions of iron sedimentation in the Lake made it possible to define its behaviour. In the proposed scheme, iron which is in particulate form undergoes an evolution in which it is dissociated from clay particles during the water concentration, and coprecipitates with silica. The oolitic structure might then form on small clay grains and sometimes quartz which is found on the Lake bottom in shallow, well aerated warm waters $\left(18\right.$ to $\left.30^{\circ} \mathrm{C}\right)$ stirred all the year long by the wind.

With the available data, the oolitic iron, on an area of $2700 \mathrm{sq} . \mathrm{km}$ and $5 \mathrm{~cm}$ mean thickness, is evaluated to be $30.10^{6}$ metric tons, expressed in pure iron. This is equal to the load of free reactive iron of the Chari during 320 years, given a constant yearly load of sediment. 
A comparative study of numerous deposits of iron-bearing oolites in the post-Eocene formations of Africa has led FAURE (1966) to define the physico-chemical conditions of oolite formation as follows: agitation during concentration, with low depth and warm temperature. Our observations corroborate these conclusions and those of BUBENICEK (1961) who writes, "iron deposition in its oxidized form, oolites growing in dynamic conditions before settling". The mechanism which is given here can also apply to the iron-bearing oolites found by LENEUF (1962) in Ivory Coast and, more generally, should be helpful when assessing the chemical conditions of the formation of iron and silica oolite beds.

The help of Mrs. Maley in the translation of this paper is gratefully acknowledged.

Bibliography

BIEN, C. S. , CONTOIS, D. E. , THOMAS, W. H. : The removal of silica from freshwater entering the sea. Geochim. Cosmochim. Acta, 14, 1, p. 35-54 (1958).

BUBENICEK, L.: Recherches sur la constitution et la repartition du minerai de fer dans 1'Aalénien de Lorraine. Sc. de la Terre $\underline{8}$, no. 1-2, p. 5-204 (1961).

CARMOUZE, J. P. : La salure globale et les salures spécifiques des eaux du lac Tchad. Cha. ORSTOM, sér. Hydrobiol. 3, 2, p. 3-14 (1970).

COONLEY, L. S. , BAKER, E. B. , HOLLAND, H. D. : Iron in the Mullica River and in Great Bay, New Jersey. Chem. Geol. 7, p. 51-63 (1971).

DEB, B. C. : The estimation of free iron oxides in soils and clays, and their removal. J. Soil Sci. 1, 2, p. 212-220 (1950).

DUPONT, B. : Distribution et nature des fonds du lac Tchad. (nouvelles données). Cah. ORSTOM, sêr. Géol. , 2, 1, p. 9-42 (1970).

FAEGRI, K. , IVERSEN, J.: Textbook of pollen analysis, $2^{\mathrm{d}}$ ed. , Munksgaard, Copenhague, 237 p. (1964).

FAURE, H. : Reconnaissance géologique des formations sédimentaires post-paléozoïques du Niger Oriental. Mém. BRGM, no. 47, 632 p. (1966).

FLEHMIG, W.: Zum Vorkommen von $\mathrm{SiO}_{2}$ in Nadeleisenerzooiden. Contr. Mineral. and Petrol. 28, p. 19-20 (1970).

FRIPIAT, J. J. , GASTUCHE, M. C. : Etude physico-chimique des surfaces des argiles. Les combinaisons de la kaolinite avec les oxydes de fer trivalents. Publ. INEAC, Sew-Scient. , no. 54, 60 p. (1952).

GUICHARD, E. : Sédimentation du lac Tchad. O.R.S.T.O. M. , Fort-Lamy, 46 p. multigr. 1 carte H. T. (1957).

LEMOALLE, J.: Premières données sur la production primaire dans la région de Bol (avril-octobre 1968) (Lac Tchad). Cah. ORSTOM, sér. Hydrobiol. 3, 1, p. $107-120$ (1969).

- Premières données sur la répartition du fer soluble dans le lac Tchad. O.R. S. T. O. M. , Fort-Lamy, ronê, 10 p. (1969). 
LENEUF, N.: Les pseudo-oolithes ferrugineuses des plages de Côte d Ivoire. C. R. Som. Soc. Géol. France $\underline{5}$, p. 145-146 (1962).

LISS, P. S. , SPENCER, C. P. : Abiological processes in the removal of silicate from sea water. Geochim. Cosmochim. Acta, 34, p. 1073-1088 (1970).

MALEY, J. : Contributions a l'étude du Bassin Tchadien. Atlas de pollens du Tchad. Bull. Jard. Bot. Nat. Belgique, 40, p. 29-48 (1970).

MORTIMER, C. H. : The exchange of dissolved substances between mud and water in lakes. J. Ecology, 29, p. 280-329 (1941).

- The exchange of dissolved substances between mud and water in lakes. J. Ecoiogy, 30, p. 147-2001 (1942).

PARKS, G. A. : Aqueous surface chemistry of oxides and complex oxide minerals. in: Equilibrium Concepts in natural water systems, W. STUMM, ed. . Am. Chem. Soc. Washington, p. 121-160 (1967).

PIAS, J.: Les formations sedimentaires tertiaires et quaternaires de la Cuvette Tchadienne et les sols qui en dérivent. Mém. ORSTOM, Paris, no. 43, 407 p. (1970).

ROBIE, R.A., WALDBAUM, D.R. : Thermodynamic properties of minerals and related substances at $298.15 \mathrm{OK}^{\mathrm{K}}\left(25.0^{\circ} \mathrm{C}\right)$ and one atmosphere $(1013$ bars $)$ pressure and at higher temperatures. U. S. Geol. Surv. Bull. 1259, 256 p. (1968).

STRICKLAND, J.D. H. , PARSONS, T. R. : A manual of sea water analysis. Fish. Res. Bd Canada, Bull. 125, 203 p. (1965).

TARDY, Y.: Géochimie des altérations. Etude des arênes et des eaux de quelques massifs cristallins d' Europe et d'Afrique. Thèse Fac. Sc. Univ. Strasbourg, 274 p. ronéo. (1969).

Address of the authors:

O. R. S. T. O. M.

B. P. 65

Fort - Lamy / Tchad 


\section{Reprint from \\ Ores in Sediments \\ Ed. by G. C. Amstutz and A. J. Bernard}

Springer-Verlag Berlin Heidelberg New York

Printed in Germany/Not for sale 